\title{
worldview
}

A JOURNAL OF RELIGION ANB INTERATIONAL AFFAIRS

\section{FOREIGN POLICY DECISIONS: WITH WHAT WISDOM ARE THEY MADE?}

President Johnson had made it clear that the present policy of the U.S. government is to use whatever force the military requires to stave off defeat in Vietram. By one of those unsettling coincidences, the President made his speech to U.S. citizens-and the rest of the world-as two members of the Kennedy administration were revealing and recounting the decisions that led, step by step, to the debacle of the Bay of Pigs. It is unsettling, of course, because the disclosures reveal in detail what was abundantly clear in general outlines from the first; a great nation like the United States, with formidable power, extensive research and intelligence services, a vast array of technical experts and politically informed advisers, can move in foreign affairs like a bull let loose among the china.

It is evident that what should have been a political decision made by the President--how best to respond to the rule of Castro in Cubawas partially informed and largely engineered by technical experts. Kennedy's own serious errors of judgement were compounded by the misguided advice and faulty information he was given. And, as Kennedy then said, "You always assume that the military and intelligence people have some secret skill not available to other people."

-

Is it possible to draw from the Bay of Pigs inferences that are applicable to the present situation in Vietram? The answer is clearly yes. Granting that each situation is unique, with a particular confluence of particulars that is never repeated, some general and important similarities can be stated. The overriding decision is, or should be, political; it should not be made by the scientific, military or technical experts. They should be regarded as the essential tools to carry out the decision.
Further, the political decision is one in which the people can and shotld participate. The factors involved are not beyond the comprehension of citizens who care to inform themselves, and the relevant information is available. President Johnson stated once again the reasons for the U.S. presence in Vietnam. These reasons remain open for discussion and agreement or disagreement. Whether one supports or opposes present U.S. policy will not be decided by some secret or arcane knowledge the government has and the ordinary citizen does not, nor should the responsible citizen feel free to withhold his own judgement on the basis that he does not know enough about the situation. If he does not, the responsibility is his to leam.

-

In the New York Times Magazine of July I8, Gunnar Myrdal recalled a statement of the Chancellor to King Gustaf Adolphus and Queen Christina of Sweden. "My son, my son," he said, "if you but knew with what little wiscon the world is ruled." And, Myrdal added, today the judgement still applies. The U.S. is not the only country capable of acting like a bull among the china. Although the problem may never be overcome it may, Myrdal suggested, be partially remedied. In words that lend support to the underlying purpose of worldoiew, he said:

"Foreign policies are as much dependent on public opinion as internal policies-if not more. At the root of the problem are fundamental deficiencies in the state of public opinion...

"One reason why the ordinary citizen is prepared to abdicate his own judgement over foreign policy is that he tends to assume that the government has information of a secret nature, not available to the general public ... experience suggests that outside of purely military matters the belief is vastly exaggerated when it is 
not entirely false: ... This debunking of the commonly assumed superior knowledge of governments is vitally important to the effective. functioning of democracy. Governments are mostly not worthy of so much respect for greater wisdom..."

This does not imply, as Myrdal is careful to note, that there is an easily tapped source of wisdom in some sector of the public. Those citizens who wish to decide policy by hurling an ethical thunderbolt at what they regard as dangerous policies must pass the same harsh tests that are imposed on government officials. What is implied is that a better foreign policy will be the result of a democracy in which citizens will have more control over foreign policy because those who are able care enough to demand the responsibility which is properly theirs. The foreign policy of a democratic nation should be a joint enterprise which those who actually make the decisions share with the citizens in whose name and for whose benefit the state acts. The further the foreign policy of the nation is from that goal, the more applicable to it is the Chancellor's statement.

J. F.

\section{in the magazines}

Which side are you on in Vietnam? Milton Kotler, a frequent contributor to Liberation magazine, says that for a number of reasons that decision is a difficult one for many Americans to make. "My genera. tion," he writes in the June-July issue, "had one good fortune, It escaped the affictions of ideology which still possess our elders. When we reached consciousness in the fifties, we faced McCarthy and Stalin, and saw both as rotten; but Stalin as no more rotten than McCarthy. That's important," Kotler notes, "to see just precisely how equal things were. Once that judgment of equality was made, then if our heart would at moments reach to Stalin, that judgment + would also carry along McCarthy. McCarthy was no more rotten than Stalin. In both men there was equal truth and falsity, equal evil and good. In short, politics after twenty years gained the light of character. Men could be judged. Isms were transcended. Thereafter we have been able to earry that tender resource of humanism to our social judgment.

"We were fortunate in the fifties. Politics became more philosophical and less active than in the thirties. It had become a field of knowledge, in which affections could be spent and reflected, More true to life." But "today we pay the price of that wiser politics." For where there is no ideology, there are no parties of history and truth. In the equality of Stalin and McCarthy, there was no party to lead the way; nor ary chance for the pleasures of heresy. Each of us had to fashion a politics, a view, a world image. For most it was a worthless task, so few have done it.

"The fifties were an isolating dccade. Events trained us never to take sides. We were always prepared to be a third force between McCarthy and the Communists. Between Israel and Egypt, America was a third force. In Greece, Lebanon, China, Guatemala, and elsewhere in the fifties, the nation played the third force. Acting for legitimacy, we were against the Communists, for self-determination. Our intervention was never for us, but for freedom and self-determination. As a policeman, our power leaped and bounded to staggering nuclear heights."

And so how ill-prepared many are when "one morning we awake and see that we are no Ionger a third force, but a major party to conflict." What side does one take in a "struggle" which "is not ideological but humanistic . . . a struggle between temperaments"? "What side do we take," Kotler asks, "without destroying our spirit, our love, our past, and the rejoicing vision with which this nation began?"

Fditor Max Ascoli criticizes as immoral in at least one respect the view taken by "neo-isolationists" toward American military commitments in Vietnam (The Reporter, July 1). He identifies these "advocates of isolationism" as the people who "incessantly tell the government: be quiet, don't overreach yourself. If you find yourself mixed up in lands too far away, gently slip out. The less you look at the So- 